№ 3 (1), 2021

УДК 519.95

A.V. Litorovych, S.A. Maslakov

Lviv Polytechnic National University

\title{
VIRTUAL ORGANIZATIONS
}

https://doi.org/

(C) Litorovych A. V., Maslakov S. A., 2021

Trends in the development of modern markets, such as the globalization, the growing importance of product quality, price and customer satisfaction, the increasing importance of sustainable relationships with consumers, the growing importance of the degree of application of new information and communication technologies and the COVID-19 pandemic have significantly influenced the development of new organizational forms of enterprise management. In this regard, the question of the impact of telecommuting on relationships and interpersonal networks within organizations has become relevant.

The aim of the article is to analyze the factors influencing to the creation and development of virtual organizations, as well as to identify types of virtual organizations. The research also covers a review of the main foreign and domestic virtual organizations.

The article considers the theoretical foundations, factors and they influencing on the formation of virtual organizations. The article analyzes the existing approaches to the definition of a virtual organization, highlights the main types of virtual structures, the main characteristics and advantages of a virtual organization, and also highlights the features characteristic of all types of virtual organizations. The features and main problems of managing virtual organizations are identified.

Virtual organization is the newest and potentially promising form of network structures, appeared and became widespread in the last decade. A virtual organization can flexibly change its configuration, where the strategic advantage of such a system provides sustainability and survival in a market economy, the ability of participants to provide flexibility and integration of resources, and the ability to quickly create virtual teams and virtual environments. However, the virtual organization has the same capabilities and potential as a traditional organization, but the virtual organization has not such institutional and structural boundaries.

Key words: virtual organizations, remote work, virtual team, virtual project, intelligent information technology, permanent virtual organization.

\section{Problem statement}

The COVID-19 pandemic has led to a surge in telecommuting in organizations, with many or even all employees working from home for extended periods of time. One of the key unforeseen consequences of the widespread transition to remote work is the impact on interpersonal relationships and networks within organizations. A better understanding of how working remotely can damage trust and collaboration will allow managers to mitigate these effects.

Analysis of recent studies and publications

J. Merkevicius, V. Davidavichene, J. Roundelunene, J. Bulecha [1, p. 202] interpret virtual organization as a form of cooperation of united human resources from different geographical locations to realize common goals, which is carried out by the personnel in accordance with the available competences. 
Sokolovsky S.A. [2, p.122] considers a virtual organization as a system of remote heterogeneous enterprises and units with the ability to change its image and configuration using network and intelligent information technology in order to optimize the income of each of the participants in a joint integration of resources.

Rud N. T. [3, p.198] considers a virtual organization as fully consumer-oriented, as its main characteristics are the speed of order fulfillment and completeness of customer satisfaction. As customers and performers are united in an open network, the boundaries between interacting organizations become fuzzy and transparent. In this case there is an integration of cultures, traditions, resources, experience and information of partner organizations. Emerges an artificial community formed electronically, which very often prolongs the life cycle of an individual organization.

A distinction is made between the concepts of virtual organization and virtual partnership.

Virtual organization is an electronic union of financial, scientific and technical, intellectual capitals in the interests of carrying out unique projects and creating a product and the fullest satisfaction of customer needs. As in the case of traditional organization, the virtual organization contributes to the solution of two basic problems of the market economy:

1) raising funds to implement unique projects or the distribution of business processes in order to increase the competitiveness of the product;

2) risk allocation in investment projects. A virtual society is a computer-integrated company of individuals who jointly conduct business for the purpose of generating income, being geographically far from each other.

A virtual partnership is a computer-integrated company of individuals who jointly conduct business for the purpose of generating income, being geographically far from each other.

Virtual organizations are divided into law, geographical, economic, and system-networks. There are also the following types of virtual organizations [4, p.97]:

a) Virtual team. The concept of virtual teams is generated by the internal organizational use of the concept of virtual organization. Virtual teams exist to work within a specific functional or technological business process within an organization;

b) Virtual project. The concept of a virtual project is used by organizations that form alliances or consortiums to bring together complementary partners. This type is most typical for virtual organizations that combine similar industries or types of enterprise;

c) Temporary Virtual Organization. This is a type of virtual project set up to implement a time-bound project or to solve a specific problem. Upon completion of the project, the virtual organization disintegrates;

d) A permanent virtual organization. It is created and, if necessary, changed to generate long-term incomes for the participants.

According to the management hierarchy virtual organizations are divided into $[5, \mathrm{p} .76]$ :

1) with a centralized type of management, where partners or agents act on behalf of their organizations. One of the agents manages the process: sets the task, gives the task to other agents, summarizes the results and makes decisions;

2) with the distributed type of management, where knowledge and resources are distributed among partners, but there remains a common command management body that makes decisions in conflict situations;

3) with the decentralized type of management, where all management processes are carried out only by local interactions between partners.

In this article we analyze permanent virtual organizations. However, at the present stage of the formation and management of virtual enterprises in the scientific literature paid insufficient attention, which determines the need for theoretical and methodological research in this direction. 


\section{Virtual organizations}

\section{Presenting main material}

Peshkova G.Y. and Pilipenko Y.A. [6] note that an important feature of virtual organizations is the shortness of their life cycle. As a rule, virtual organizations function from a few months to one year, that is, in the short and medium term. This prevents the execution of complex and detailed contracts that determine the role of participants in the distribution of the final financial result.

Virtual organization is a network, computer-mediated organizational structure consisting of heterogeneous components located in different places. That, in turn, is created by combining the organizational and technological resources of a set of organizations and their integration through the use of a computer network. The necessity of creation structures of virtual type in the world practice is caused by the following circumstances, as globalization of markets and desire to enter the world market, and the need for constant adaptation to the dynamic external environment. However, the virtual organization has the same opportunities and potential as the traditional one, but the virtual organization has no similar institutional and structural boundaries. The virtual marketplace operates continuously in real time, encompasses the entire world and allows for a variety of virtual transactions such as buying, selling, training, banking, virtual fairs, etc.

We can distinguish the following factors influencing the emergence and development of virtual organizations (Tab. 1).

Table 1

Factors that influence the emergence and development of virtual organizations

\begin{tabular}{|l|c|c|}
\hline № & Factor & Influence \\
\hline 1 & $\begin{array}{c}\text { Fierce competition, } \\
\text { personalization }\end{array}$ & $\begin{array}{c}\text { Ability to manage production adapted to the needs of each } \\
\text { specific customer or customer of a mass-produced product or service }\end{array}$ \\
\hline 2 & $\begin{array}{c}\text { The emergence of } \\
\text { electronic money }\end{array}$ & $\begin{array}{c}\text { Integration of modules into the management system, which allow } \\
\text { you to operate various financial instruments }\end{array}$ \\
\hline 3 & $\begin{array}{c}\text { Development of } \\
\text { information technologies as the } \\
\text { main tool to increase efficiency }\end{array}$ & $\begin{array}{c}\text { The operation of the management system is based mainly on } \\
\text { information technology }\end{array}$ \\
\hline 4 & $\begin{array}{c}\text { The rate of change in } \\
\text { the environment }\end{array}$ & $\begin{array}{c}\text { all companies will strive to respond to any changes as soon as } \\
\text { possible }\end{array}$ \\
\hline 5 & Globalization & $\begin{array}{c}\text { Companies compete not only with their close rivals, but also with } \\
\text { competitors around the world }\end{array}$ \\
\hline 6 & Cost & $\begin{array}{c}\text { reducing the cost of market entry, especially in information and } \\
\text { technology-oriented industries }\end{array}$ \\
\hline
\end{tabular}

Source: own development based on [3, p.91; 7, p.130]

The following characteristic features of a virtual organization can be identified [8, p.225-226]:

- a high proportion of intangible assets in the structure of assets;

- instability of capital structure;

- a high degree of uncertainty and risk of cash flows;

- insignificant volume of depreciation deductions;

- lack of correlation between the rate of change in income and expenses;

- a clear development of the virtual organization according to the phases of the life cycle: ideaimplementation-intensification-life span;

- growing volume of investment in accordance with the growing demands of the market.

Virtual organizations are created as a system of artificially integrated in the information space diverse organizations with a unified management system, which can flexibly change its configuration. The strategic advantage of such a system is sustainability and survival in a market economy, as well as the ability of participants to provide flexibility and integration of resources, the ability to quickly create virtual teams and virtual environment, combining the knowledge of competent people for targeted activities (Table 2). 
The characteristics of a virtual organization

\begin{tabular}{|c|c|c|}
\hline Characteristics & Benefits & Disadvantages \\
\hline $\begin{array}{l}\text { integration of the best technologies, } \\
\text { means of production and experience } \\
\text { within strategically expedient } \\
\text { associations }\end{array}$ & $\begin{array}{l}\text { the ability to choose and use the } \\
\text { best resources, knowledge and } \\
\text { skills with the least amount of } \\
\text { time }\end{array}$ & $\begin{array}{l}\text { the high costs associated with } \\
\text { investments in information and } \\
\text { communication technology and the } \\
\text { associated operating costs }\end{array}$ \\
\hline $\begin{array}{l}\text { accumulation of resources for key } \\
\text { business processes }\end{array}$ & $\begin{array}{l}\text { Ensuring timely execution of } \\
\text { key business processes }\end{array}$ & increase in total costs \\
\hline $\begin{array}{l}\text { creation of autonomous working } \\
\text { groups that are geographically } \\
\text { remote }\end{array}$ & $\begin{array}{l}\text { increasing the speed of market } \\
\text { order execution }\end{array}$ & $\begin{array}{l}\text { Overdependence on partners } \\
\text { economically, due to the narrow } \\
\text { specialization of network members }\end{array}$ \\
\hline $\begin{array}{l}\text { temporary nature of partnership, } \\
\text { flexibility, possibility of } \\
\text { restructuring }\end{array}$ & $\begin{array}{l}\text { possibility of full satisfaction of } \\
\text { requirements of the customer }\end{array}$ & $\begin{array}{l}\text { practical lack of social and material } \\
\text { support of their partners due to the } \\
\text { abandonment of the classic long-term } \\
\text { contractual forms and normal } \\
\text { employment relationships }\end{array}$ \\
\hline $\begin{array}{l}\text { Combining the functions of } \\
\text { centralization and decentralization } \\
\text { in management by the advantage of } \\
\text { elements of decentralization }\end{array}$ & $\begin{array}{l}\text { flexible adaptation to changes } \\
\text { in the environment }\end{array}$ & $\begin{array}{l}\text { diversity of employees due to the origin of } \\
\text { different cultures and geographical } \\
\text { regions, which creates psychological } \\
\text { barriers between employees and customers }\end{array}$ \\
\hline $\begin{array}{l}\text { intensive use of remote } \\
\text { communication means the vast } \\
\text { majority of coordination links }\end{array}$ & $\begin{array}{l}\text { Reducing the barriers } \\
\text { associated with the territorial } \\
\text { fragmentation of units } \\
\text { (including in different } \\
\text { countries) }\end{array}$ & $\begin{array}{l}\text { legal issues related to different rules } \\
\text { governing the use of information in } \\
\text { different countries, which is not always } \\
\text { noticeable to employees of a virtual } \\
\text { enterprise }\end{array}$ \\
\hline $\begin{array}{l}\text { wide distribution and redistribution } \\
\text { of powers of management of the } \\
\text { organization }\end{array}$ & $\begin{array}{l}\text { the possibility of parallel } \\
\text { control of different processes of } \\
\text { production of goods and } \\
\text { services }\end{array}$ & $\begin{array}{l}\text { the creation of a virtual enterprise forces } \\
\text { to take into account the possibility of } \\
\text { additional risks }\end{array}$ \\
\hline $\begin{array}{l}\text { organization of interaction between } \\
\text { specialists based on the use of } \\
\text { computer technology }\end{array}$ & $\begin{array}{l}\text { increasing the speed of market } \\
\text { order execution }\end{array}$ & $\begin{array}{l}\text { insufficient motivation of network } \\
\text { participants, the need to develop original } \\
\text { approaches to managing virtual } \\
\text { organizations }\end{array}$ \\
\hline $\begin{array}{l}\text { development of heterogeneous } \\
\text { computer networks and } \\
\text { environments, the use of various } \\
\text { software tools }\end{array}$ & $\begin{array}{l}\text { strengthening the } \\
\text { competitiveness of } \\
\text { organizations through the speed } \\
\text { of creation and search for new } \\
\text { knowledge, ensuring the } \\
\text { reliability of information } \\
\text { storage }\end{array}$ & potential software incompatibility \\
\hline
\end{tabular}

Source: own development based on [3, p.91-92; 9, p.34; 10]

Among the disadvantages of the virtual organization is that with the transition to virtual cooperation the number of employee interactions decreases, relationships weaken, work networks shrinks, making the organization less interdependent. Levin Z.D. [10] notes that, virtual communication, not to mention the experience of being in crisis mode, makes people more negative, more distracted, less inclined to cooperate with others, less inclined to share useful information, less trusting and less inclined to listen to new ideas.

Illustrative examples of foreign organizations using virtual teams are SAP and IBM. Also of note are companies that use virtual marketplaces, such as Amazon.com and AliExpress. 


\section{Virtual organizations}

SAP has the title of the world's largest software company, with more than 30,000 employees in 60 countries who collaborate in virtual teams. SAP has structured itself strategically, with global headquarters in Germany and R\&D centers in India, China, Israel and the United States, where each center has specific expertise that it shares with the entire company, reducing costs. Managers can assemble virtual teams that include employees from each of these special groups, making each team more sophisticated [11].

IBM has more than 200,000 employees from all over the world. One of the main problems for a global company of this size is time zone management. IBM allows employees to work the hours when they are the most from nature, increases their productivity and improves morale [12]. IBM's ability to make the most of remote networking and virtual teams contributes to its continued success in the world and the ongoing development of information technology.

In Ukraine, virtual organizations are actively created and developed. Thus, the leader among virtual organizations is the holding company KM Core. The main directions of the company's business are: information and communication technologies, microelectronics, environmental and energy-saving technologies [13].

Illustrative example of virtual organizations in the market of Ukraine is e-commerce, which involves the trade of goods through the Internet. To date, this industry in Ukraine has about 5000 electronic stores.

At the market of financial services in Ukraine we can note a steady trend of development of virtual banking systems [14].

\section{Conclusion}

Virtual organization in a broad sense defines one of the new and potentially highly effective forms of enterprise organization, is the best under certain technical and economic conditions. Virtual organizations can be defined as the basis of a network economy, has no industry or departmental barriers, as well as an open organizational structure and transparent boundaries, resulting in an increase in the importance of partnerships.

In general, virtual organizations are created as systems of heterogeneous enterprises artificially integrated in the information space with a single management system. This helps virtual organizations to flexibly change their configuration, where the strategic advantage of such a system provides stability and survival in the market economy, the ability of participants to provide flexibility and integration of resources, the ability to quickly create virtual teams and virtual environment, to combine the knowledge of competent individuals for targeted activities, which is very relevant in today's environment.

It is worth noting that the virtual enterprise has the same opportunities and potential as the traditional one, but the virtual enterprise has no such institutional and structural boundaries.

\section{Список використаної літератури}

1. Merkevicius J., Davidaviciene V., Raudeliuniene J., Buleca J. (2015) Virtual organization: Specifics of creation of personnel management system. E a m: Ekonomie a Management, Vol 18 \# 4, pp. 200-211.

2. Соколовський С. А. Моделювання інноваційної діяльності віртуального підприємства в умовах інформаційної економіки. Вісник економіки транспорту і промисловості. 2017. Вип. 57, С. 120-128.

3. Рудь Н., Мохнар М. Віртуальні підприємства: сутність та доцільність використання в інноваційній діяльності. Економічний форум. 2016. № 4, с.197-207.

4. Хромов I. Е. Основные виды и характеристики виртуальных организаций в экономике. Bопросы экономики и права. 2018. Вип. 8. № 122, с. 95-99

5. Тимашова Л. А. О проблемах создания и развития виртуальных систем. Управляющие системы и машины. 2017. № 2, С. 74-82.

6. Пешкова Г.Ю., Пилипенко Ю.А Актуальность компетентностного подхода в управлении виртуальными организациями. Известия юго-западного государственного университета. серия: Серия: Экономика. Социология. Менеджмент. 2019. Т. 9, № 4. Юго-Западный государственный университет (Курск) 2019.

7. Загорна Т. О., Ткачова А. В. Віртуальні організації в умовах інформаційної економіки: специфіка діяльності, конкурентні переваги. Экономика: реалии времени. 2014. № 6, с. 128-135 
8. Сентябов, Ю. Н., Андреева, М. Ю. Оценка стоимости виртуальной организации как основа принятия инвестиционного решения. Современные научные исследования: актуальные теории и концепџии: материалы Всероссийской (национальной) дистанционной научно-практической конференции, г. Саратов. 2020 , c.224-228.

9. Пузирьова П. В. Сучасні аспекти менеджменту віртуальних підприємств. Стратегічні пріоритети розвитку економіки, фінансів, обліку та права в Україні та світі : збірник тез доповідей міжнародної науково-практичної конференції, м. Полтава, 3 жовтня 2019 року. Полтава: ЦФЕНД, 2019, С. 33-34.

10. Levin, D. Z., \& Kurtzberg, T. R. (2020). Sustaining employee networks in the virtual workplace. MIT Sloan Management Review, vol 61, № 4, pp.13-15

11. Lepsinger Rick (2017) 3 Companies With High-Performing Virtual Teams. URL: https:/www.bestpracticeinhr.com/3-companies-with-high-performing-virtual-teams/

12. OHIO university. Managing Virtual Teams Domestically And Internationally. URL: https://onlinemasters.ohio.edu/blog/managing-virtual-teams-domestically-and-internationally/

13. КM Core: веб-сайт. URL: http://www.kmcore.com/rum

14. Журавель А.І., Комарова К.В. Віртуальні організації в умовах глобалізації: розвиток та особливості управління. Шестнадцатые экономико-правовые дискуссии 13 березня 2017. Секція 2 Менеджмент. URL: http://www.spilnota.net.ua/ua/article/id-1734/

\section{References}

1. Merkevicius J., Davidaviciene V., Raudeliuniene J., Buleca J. (2015) Virtual organization: Specifics of creation of personnel management system. E a m: Ekonomie a Management, Vol 18 \# 4, pp. 200-211.

2. Sokolovskyi S. A. (2017) Modeliuvannia innovatsiinoi diialnosti virtualnoho pidpryiemstva $\mathrm{v}$ umovakh informatsiinoi ekonomiky [Modeling innovation activities virtual enterprises in the information economy] Visnyk ekonomiky transportu i promyslovosti [The bulletin of transport and industry economics], \# 57. pp. 120-128.

3. Rud N., Mokhnar M. (2016) Virtualni pidpryiemstva: sutnist ta dotsilnist vykorystannia $\mathrm{v}$ innovatsiinii diialnosti [Virtual enterprises: nature and feasibility of using in innovative activity] Ekonomichnyi forum [Economic forum], \# 4, pp.197-207.

4. Khromov I.E. (2018) Osnovni vydy i kharakterystyky vyrtualnykh orhanyzatsii v эkonomitsi [Main types and characteristics of virtual organizations in economics] Эkonomyka i upravlenye narodnum khaziaistvom [Economy and federal management]. Voprosy ekonomiki i prava, vol 8 \#122, pp. 95-99

5. Tymashova L. A. (2017) O problemakh sozdanyia i razvytyia vyrtualnыkh system [About Problems of Creation and Development of the Virtual Systems]. Systemy keruvannia ta kompiutery [Control systems \& computers], \# 2, pp. 74-82

6. Peshkova H.Yu., Pylypenko Yu.A.( 2019) Aktualnost kompetentnostnoho podkhoda v upravlenyy vyrtualnыmy orhanyzatsyiamy. [Relevance of competence approach in management of virtual organizations] Izvestyia Yuho-Zapadnoho hosudarstvennoho universyteta. Seriia Эkonomika. Sotsiolohiia. Menedzhment [Bulletin of the South-West State University. Series Economics. Sociology. Management], vol 9, \#4, pp.27-32

7. Zahorna, T. O., \& Tkachova, A. V. (2014) Virtualni orhanizatsii v umovakh informatsiinoi ekonomiky: spetsyfika diialnosti, konkurentni perevahy [ Virtual organizations in the information economy: the specifics of the activity, competitive advantages] Эkonomyka: realyy vremeny [Economics: time realities], vol 6, \#16, pp. 138-135

8. Sentyabov Yu.N., Andreeva M.Yu. (2020) Otsenka stoymosty vyrtualnoi orhanyzatsyy kak osnova pryniatyia ynvestytsyonnoho reshenyia [Valuation of value of virtual organization as a basis for making an investment decision] Sovremennыe nauchnыe yssledovanyia: aktualnыe teoryy y kontseptsyy: Materyaly Vserossyiskoi (natsyonalnoi) dystantsyonnoi nauchno-praktycheskoi konferentsyy [Modern scientific research: current theories and concepts: Materials of the All-Russian (national) remote scientific-practical conference], Saratov: FGBOU VO Saratov GAU, pp. 224-228

9. Puzyrova, P. V. (2019) Suchasni aspekty menedzhmentu virtualnykh pidpryiemstv [Modern aspects of virtual enterprise management] Stratehichni priorytety rozvytku ekonomiky, finansiv, obliku ta prava v Ukraini ta sviti : zbirnyk tez dopovidei mizhnarodnoi naukovo-praktychnoi konferentsii [Strategic priorities of economic development, finance, accounting and law in Ukraine and the world: a collection of abstracts of the international scientific-practical conference], Poltava: CFEND, pp. 33-34

10. Levin, D. Z., \& Kurtzberg, T. R. (2020). Sustaining employee networks in the virtual workplace. MIT Sloan Management Review, vol 61, \#4, pp. 13-15 
11. Lepsinger Rick (2017) 3 Companies With High-Performing Virtual Teams. Retrieved from: https:/www.bestpracticeinhr.com/3-companies-with-high-performing-virtual-teams/

12. OHIO university. Managing Virtual Teams Domestically And Internationally. Retrieved from: https://onlinemasters.ohio.edu/blog/managing-virtual-teams-domestically-and-internationally/

13. КМ Core. Офіційний сайт. Retrieved from: http://www.kmcore.com/rum

14. Zhuravel A.I., Komarova K.V. (2017) Virtualni orhanizatsii v umovakh hlobalizatsii: rozvytok ta osoblyvosti upravlinnia [Virtual organizations in the conditions of globalization: development and features of governance] Retrieved from: http://www.spilnota.net.ua/ua/article/id-1734/

Літорович О.В., Маслаков С.О. Національний університет “Львівська політехніка"

\section{ВІРТУАЛЬНІ ОРГАНІЗАЦЇ̈}

(C) Літорович О.В., Маслаков С.О., 2021

Тенденції розвитку сучасних ринків, такі як глобалізація ринків, зростаюче значення якості товару, його ціни і ступеня задоволення споживачів, підвищення важливості стійких відносин зі споживачами, зростаюче значення ступеня застосування нових інформаційних i комунікаційних технологій, а також епідемія COVID-19 суттсво вплинули на розвиток нових організаційних форм управління підприємством.

У статті виявлено чинники, що впливають на створення і розвиток віртуальних організацій, а також встановлено класифікацій віртуальних організацій та їх основні переваги i недоліки.

Ключові слова: віртуальні організації, віддалена робота, віртуальна команда, віртуальний проект, інтелектуальні інформаційні технології, постійно діюча віртуальна організація. 